HISTORY OF MEDICINE

\title{
Holistic obstetrics: the origins of "natural childbirth" in Britain
}

\section{O Moscucci}

Postgrad Med J 2003;79:168-173

The term "natural childbirth" denotes an approach to childbirth characterised by a bias towards physical and mental hygiene in the management of pregnancy and labour. It emerged in Britain in the interwar period, partly as a response to the growing interventionism of mainstream obstetrics. Its appeal since then has rested on the belief that it could provide a holistic approach to maternity care, capable of addressing the needs of the "whole" patient. At the same time, "natural childbirth" has provided a means of expressing anxieties about the social, economic and political upheavals of the 20th century. This paper explores this complex set of beliefs and practices by examining the ideas of some British pioneers.

Correspondence to: Dr Ornella Moscucci, Department of Public Health and Policy, London School of Hygiene and Tropical Medicine, Keppel Street, London WCIE 7HT, UK; Ornella.Moscucci@ Ishtm.ac.uk

Submitted 2 August 2002 Accepted

11 December 2002
M dern obstetrical practice has been transformed by the growth of new technologies. This transformation, however, has not been universally or unconditionally welcomed. From time to time, doubts have been expressed about the appropriateness of these new techniques, not least from within the medical profession itself.

In 20th century Britain, resistance to obstetrical technology has been epitomised by the development of concepts of maternity care commonly known as "natural childbirth". The term derives from the title of a short treatise on labour pain published in 1933 by the English general practitioner Grantly Dick-Read (1890-1959). It was later used more generally to describe an approach to childbirth that emerged in Britain between the two world wars, in opposition to other approaches that were characterised as excessively narrow or reductionist in focus. The appeal of natural childbirth throughout the 20th century has largely rested on the belief that its methods could provide a holistic approach to maternity care, capable of integrating the physiological, psychological, social, and spiritual aspects of reproduction. ${ }^{1}$

It must be emphasised that natural childbirth has never been a system or an entity, but an umbrella term for a variety of different techniques. What these techniques have in common is a bias towards physical and mental hygiene in the management of pregnancy and birth. ${ }^{2}$

At a different level, natural childbirth has served as a form of cultural and political critique aimed at various crises of modern Western society, from industrialism, capitalism and materialism, to urbanisation and mass culture. The solution to these evils has been seen to lie in a return to "nature", variously defined as the country, the primitive, the spiritual, and the instinctual. "Nature" has also been strongly associated with putatively feminine values such as love, cooperation and altruism, in opposition to the destructive qualities traditionally vested in the male.

To understand these ideas, it is necessary to resist any attempt to regard natural childbirth as a universal, value-free category and look at the intellectual and political context in which it was embedded.

\section{POPULATION CONCERNS}

Natural childbirth emerged in Britain at a time of deepening gloom about the quality of modern life and civilisation. From the late 19th century onwards, new anxieties about the hereditability of disease and the application of evolutionary principles to sociological theory led to a widespread belief that the processes of biological and social evolution had gone into reverse..$^{3-5}$ The decline in the birth rate and the existence of an urban "residuum" of destitute and sickly individuals fuelled anxieties about race degeneration and social decline, stimulating a quest for national efficiency which crossed all party lines. ${ }^{6}$

Health policy became the subject of intense public debate in the aftermath of the Boer war, when Britain's near defeat at the hands of a barely trained army focused the attention on the physical fitness of new recruits. Those who saw the problems of ill health as environmental argued for an extension of the preventive medical programmes championed by the public health services. $^{7-10}$ Adherents to the new science of eugenics on the other hand blamed heredity. In their view, health policy should aim to prevent reproduction among "low quality" human stock ("negative" eugenics), and encourage reproduction among "good" stock ("positive" eugenics). ${ }^{11}$

Some groups and individuals sought to synthesise these two approaches. Health reform organisations such as the People's League of Health

Box 1: The ideology of natural childbirth

- Nature: culture

- Woman: man.

- Country: city.

- Primitive societies: civilisation.

- Physiology: pathology.

- Altruism: selfishness.

- Vegetarianism: meat eating.

- Mothering: thinking.

- Spirituality: materialism.

- Nature: science and technology. 
(founded in 1917) and the New Health Society (founded in 1927) tried to develop a reformist eugenics, which mixed theories of environmental improvement with theories of selective breeding to produce a better future for human society. ${ }^{12}$ The development of "natural childbirth" owed much to the activities of physicians and health professionals who were in sympathy with the aims of reform eugenics.

In common with hardline eugenists, these health reformers were concerned about the differential birth rate-the tendency of poorer, less healthy sections of society to have larger families than their "betters". Thus, as well as endorsing plans for the sterilisation and detention of "degenerates", they also sought to encourage the middle classes to have more children. The assumption here was that socioeconomic and psychological factors were behind the fall in the birth rate of this section of the population. Attention was drawn to the cost of raising a family and to the impact of female emancipation on fertility. Female education and employment were seen as a particular evil, insofar as they led women to regard motherhood a burden and to neglect hearth and home.

The fear of childbirth was also frequently mentioned as one of the reasons why middle class women were shirking their reproductive duties. ${ }^{13}{ }^{14}$ This belief helped fuel support for obstetric analgesia, an issue that was of particular concern to women's groups. ${ }^{15}$ In Britain the National Birthday Trust Fund (founded in 1928) campaigned for wider access to obstetric analgesia in domiciliary practice. ${ }^{14-16}$ "Twilight sleep", a form of anaesthesia that combined scopolamine and morphine, was promoted mainly by wealthy American feminists, with limited results. ${ }^{17-19}$

One obvious way to reverse the falling birth was to entice women of "superior stock" back into the home, where they would fulfil their functions as wives and mothers. Health reformers took up the challenge by developing an ideology of childbirth that emphasised the "naturalness" of pregnancy and birth. This ideology functioned at a number of levels. It was prescriptive, in that it rooted woman's social role in her biological capacity for reproduction. The redefinition of labour as "hard work", an expression that alluded to woman's vital economic role as the producer of babies, is particularly revealing in this respect. ${ }^{20}$ But this emphasis on woman's biological functions was not intended to be confining or belittling. Motherhood was not only a woman's supreme fulfilment and reward, but also her civic duty. As eugenist and health reformer Caleb Saleeby explained in 1909: "The history of nations is determined not on the battlefield but in the nursery, and the battalions which give lasting victory are the battalions of babies. The politics of the future will be domestic". ${ }^{21}$

The term "natural" also conveyed the idea of physiological norm. Health reformers were at pains to show that pregnancy and parturition were not pathological processes. Obstetrician Kathleen Vaughan made this point by contrasting the women who saw childbirth as an illness with the "true athletes", the women who carried out their "appointed work" joyfully and successfully. Vaughan went on to say: "Is not this the spirit in which the relays of bearers of the sacred torch leapt to their task, the spirit in which the great sculptor approaches his block of marble from which will spring the embodiment of his genius? He embodies his idea in marble, while women are bearers of the life of the race" ${ }^{\prime 22}$ Ideas about the normality of childbirth suggested that a positive attitude towards pregnancy and birth was essential if the "lamp of the Anglo Saxons" was not to burn dimly. ${ }^{23}$

\section{CIVILISED BIRTH}

In the years immediately after the First World War, such views were distinctly at odds with most people's perceptions of childbirth. Belief in the pathological nature of childbirth had been gathering momentum since the end of the 19th century. The rise in maternal mortality between 1910 and 1914 merely served to heighten this perception, reinforcing the belief that childbirth could not be regarded as a "natural" physiological process. ${ }^{24}$

A commonly held view at the time was that civilisation had so weakened women as to render physiological childbirth impossible. This belief stemmed from a tradition established in the Enlightenment. In the late 18th century, philosophes such as Rousseau and Diderot had contrasted the healthy lifestyle of the "noble savage" with the artificial manners of the upper classes, arguing that luxury, fashion, and city life were inducing habits that were detrimental to health. ${ }^{25}{ }^{26}$ By the late 19th century, this notion had found its way into obstetrics thanks to George J Engelmann (1847-1903), Professor of Obstetrics at Missouri Medical College. In Labour among Primitive People, Engelmann claimed that:

"Among primitive people, still natural in their habits and living under conditions which favour the healthy development of their physical organisation, labour may be characterised as short and easy, accompanied by few accidents and followed by little or no prostration... The squaws of the Madoc Indians-a tribe which has been little but affected by the advance of civilisation-suffers but an hour or even less in the agony of childbirth . . .two hours being the average time for North American Indians". ${ }^{27}$

"Unnatural" customs such as tight-lacing, education, and lack of exercise led to difficult and long labours; they produced malpositions and a "languid neurasthenic condition". Other authors included the robust women of the working classes with the primitives. The German pioneers of twilight sleep, for example, argued that civilisation increased the sensitivity of the nervous system to pain. They thus claimed that the technique was best suited for the upper class "modern woman . . . [who] responds to the stimulus of severe pain ...with nervous exhaustion and paralysis of the will to carry labour to conclusion". They were less sure that it was necessary for women from the labouring classes, who could tolerate more pain. ${ }^{28}$

Variables such as diet, exercise and occupation were, at least in principle, amenable to change. Not everyone, however, was optimistic about the possibility of improving the mortality and morbidity of childbirth through changes in women's behaviour. Most doctors in fact interpreted Engelmann's ideas as a justification for a more interventionist approach to labour. As a general practitioner argued in 1906, "nature intended women to deliver themselves easily, but civilization, injudicious breeding and modes of dress and occupation have interfered, and the art of midwifery must come to the rescue ... If anything savours of being 'almost criminal' it is the turning out on the public of young doctors who have never used the forceps". ${ }^{29}$

\section{CONSTRUCTIVE PHYSIOLOGY}

Such beliefs were in part responsible for hastening the interventionist trend that had been in evidence in obstetrics since the early 1870s. By the 1920s anaesthesia and forceps deliveries had become commonplace in obstetrical practice. At the same time, there was mounting concern about the extent of "meddlesome midwifery" in general practice and its implications for maternal mortality. Government officers, obstetric specialists, and general practitioners themselves deplored the tendency to intervene as an "orgy of interference", claiming that the penalty for unnecessary intervention was high maternal mortality and morbidity. ${ }^{24}$

Health reformers joined the chorus of disapproval to argue the case for radical reform in the management of childbirth. In contrast to the majority of medical practitioners, they were confident that the ill effects of civilisation could be reversed if women reformed their habits and adopted a more "natural" mode of life. Education, not intervention, was the key to improvements in maternity care. As Dick-Read wrote in 1942: 
"Education and research are the essential of progress, particularly in child production ... the mother is the factory, and by education and care she can be made more efficient in the art of motherhood". ${ }^{30}$

Arguments against obstetrical intervention were not purely medical, however. Religious and moral considerations also played an important part. In the cosmology of health reformers, physical health was a state of spiritual and bodily wholeness, disease a fall from grace; healing could be attained by favouring God's "natural" cures rather than the artificial remedies of orthodox medicine. It is no accident that nonconformists, Christian Scientists, and theosophists were prominently involved in the movement for natural childbirth as indeed they were in other health reform causes. Health reformers were disaffected with official creeds and orthodox medicine alike, seeking to replace both with a unified, holistic philosophy of spiritual and bodily health. In so doing they harked back to traditional values, which they located in an organic past or in the rural community. ${ }^{12}$

The work of health reformer John Shields Fairbairn (18651944), consultant obstetrician at St Thomas' Hospital and second President of the British (later Royal) College of Obstetricians and Gynaecologists, illustrates several of the themes discussed so far. Fairbairn is not usually associated with the development of natural childbirth, yet his influence on that movement cannot be underestimated. It is thus important to describe his views in some detail. The son of a distinguished Congregationalist theologian, Fairbairn was a reform eugenist with a keen interest in questions of national efficiency. In the 1920s he joined the People's League of Health, and he gave public support to the Eugenics Society's sterilisation campaign. At the same time, Fairbairn firmly believed in the value of preventive medicine, and he was a pioneer of antenatal care in London.

Fairbairn encouraged the expansion of physiotherapy into maternity care, thus laying the foundations for the development of obstetric physiotherapy in the late 1940s. Just before the First World War, he persuaded Minnie Randell, the head of the physiotherapy department at St Thomas', to initiate a programme of postnatal exercises for the mothers under his care. During the 1920s the scope of the programme was extended to include antenatal instruction and training. Randell, who was a trained nurse and midwife, pioneered the application of massage and relaxation techniques in childbirth, later to become common to most methods of natural childbirth. ${ }^{231}$

Underlying Fairbairn's initiatives was a new conception of positive health. Fairbairn believed that the primary purpose of prevention in midwifery should be the attainment of normal function rather than the detection of abnormalities. He called this approach "constructive physiology", in opposition to the hunt for "destructive pathology". The latter, he thought, had become too prominent in antenatal work. There had been too much "veterinary" practice in obstetrics, he argued; too much attention had been paid to biochemical reactions at the expense of psychological and social factors. In order to correct this narrow, dehumanising focus, obstetricians needed to widen their horizons and consider the whole range of the physical, mental, and social influences that affected the health of the expectant mother. ${ }^{32} 33$

Thus Fairbairn strongly backed the alternative approaches to maternity care advocated by his former pupil Dr Cyril Pink (1894-1965) and by fellow medical practitioner Grantly DickRead. Pink, who was a theosophist and a disciple of Maximilian Bircher-Benner, the Swiss nutritionist of "muesli" fame, argued that a natural mode of life in pregnancy, combined with a diet of fruit, salads, nuts and vegetables, was the best possible protection against abnormality during pregnancy and birth. ${ }^{34}{ }^{35}$ In evidence Pink pointed to the exceptionally low incidence of puerperal fever and toxaemia at the Stonefield Maternity Clinic, which he ran in partnership with Dr White. However, the significance of vegetarianism for Pink went far beyond its immediate health benefits. Vegetarianism embodied the nurturing, caring qualities associated with femininity. Meat eating on the other hand was equated with masculinity. It fed the "carnal appetites" and the "anti-social emotions" that led to sexual immorality and social strife. Thus, by feeding herself on the simple fruits of the earth, the expectant mother would make it easier for her child to develop the qualities that made for good citizenship and world peace. ${ }^{36}$

Grantly Dick-Read shared Pink's belief that society's hopes for regeneration lay in a return to a more natural mode of birth; however, he was somewhat sceptical that vegetarianism was the way forward. In his view, the psychological make-up of modern woman was far more significant than diet or exercise: "for motherhood is of the mind, and the body is usually subjected to the mental processes, unless any gross abnormality exists" ${ }^{30}$ This psychosomatic approach informed DickRead's attempt to solve one of the most urgent obstetrical problems of his day: the relief of pain in labour.

\section{PSYCHOLOGY OF PREGNANCY}

The work of Grantly Dick-Read, the spiritual father of natural childbirth, encapsulates many of the themes outlined so far. Dick-Read was a social reformer with a strong interest in preventive medicine. He was also a profoundly religious man, fired by an evangelical faith in the spiritual significance of motherhood. Dick-Read believed that childbirth revealed God's presence in the universe: it was the task of science to render it explicit, by showing the laws of nature that governed the processes of birth. Dick-Read accordingly rejected materialistic and mechanistic interpretations of pregnancy and birth. In their place he developed a theory of childbirth that sought to integrate body and mind, individual and culture.

Dick-Read was born at Beccles, Suffolk, in 1890, the sixth of the seven children of Robert Read, a miller, and of his wife Francis Maria Sayer. In his early youth he had intended to enter the Church as a Congregationalist minister, but he later gave up the idea, settling for a career in medicine instead. He received his medical education at Cambridge University and at the London Hospital, qualifying with the English Conjoint Diplomas in 1914. After the First World War he held a number of resident house appointments at the London, including one to Henry Head, the distinguished neurophysiologist. This association partly explains Dick-Read's subsequent interest in the neurophysiology of pain, a field towards which Head's studies of the thalamic syndrome and of visceral pain had made an important contribution. ${ }^{37}$ After leaving the London and settling in general practice in Woking, Surrey, Dick-Read began to devote much of his spare time to the study of labour pain. By early 1933 he had completed a manuscript entitled "The Psychology of Pregnancy", which was published later that year under the title Natural Childbirth..$^{38}$

The book, the first of many on the subject, had been prompted by eugenic concerns about the decline in middle class fertility. Echoing other contemporary observers, DickRead believed that the fear of childbirth was deterring the better off from having large families. However, he argued that the problem could not be overcome simply by providing wider access to pain relieving drugs. Dick-Read's objections were twofold-medical and moral. First, obstetric analgesia and anaesthesia encouraged meddlesome midwifery, thus indirectly increasing the risks of childbirth. Second, they prevented mothers from being fully conscious at the moment of birth. This was important to Dick-Read because he believed that the "spirit of motherhood" remained dormant unless it was awakened by the first cry of the baby. He was thus especially critical of twilight sleep because, quite apart from its poor safety record, it prevented women from forming an emotional attachment to their babies.

The argument developed in Natural Childbirth and in its more famous sequel, Revelation of Childbirth (subsequently 
Childbirth Without Fear), mixed Darwinian themes, neurophysiological theories, and cultural stereotypes of childbirth among "primitive" people. ${ }^{30} 38$ (39 Dick-Read accepted the theory that pain supposed a transition from a sensory to a perceptual state, as well as implicating complex emotional reactions associated with prior experience. In his definition labour pain was "a psychic stimulus, reproduced from misconceptions based upon culture". Nature, he argued, had never intended childbirth to be painful; on the contrary, it had made parturition "consequent upon irresistible and pleasurable demands" so that "the stimulus of procreation may over-rule all other demands, that the species may survive". ${ }^{38}$

Whether women experienced pain or not depended on cultural attitudes to childbirth rather than on some property inherent to parturition. Dick-Read developed this argument by contrasting the experience of birth in "primitive" and "cultured" societies. Drawing on the anthropological literature of the late 19th century, he claimed that primitives experienced easy, painless labours. This was because in primitive societies the survival value of childbirth was fully appreciated and labour was regarded as nothing more than "hard work" in the struggle for existence. In civilised societies on the other hand a number of cultural factors conspired to distort woman's natural capacity for painless birth, producing in woman a fear of childbirth that hindered normal parturition. When labour began, fear triggered a flight-or-fight response that caused tension in the cervix. The resulting struggle between contracting uterine muscles and resisting cervix was the reason why women experienced pain in childbirth.

To eliminate pain, the fear-tension-pain cycle must be broken: modern woman must learn to discipline her emotions. Women had to be "tactfully, gradually and carefully initiated into the job they were about to perform".$^{38}$ Education in the "facts" of natural childbirth and instruction in the methods of relaxation were the chief weapons in the battle against fear. However, neither was likely to be effective if the doctor-patient relationship was poor. Cooperation and mutual confidence between the patient and her attendants were essential to the maintenance of healthy pregnancy and birth. ${ }^{38}{ }^{40}$ According to Dick-Read, these psychological techniques would not only eliminate pain, but also shorten labour and reduce the need for surgical interference.

By the 1950s, with the help of Dick-Read's second wife Jessica, these ideas had developed into a programme of antenatal classes, which also included some of the exercises devised by Minnie Randell. However, Dick-Read always insisted that the emphasis placed by physiotherapists on physical exercise was misguided. Natural childbirth was not a system of gymnastics but a philosophy of birth and a blueprint for a reformed society.

By arguing that motherhood was a sacred calling, Dick-Read sought to appeal to the middle classes' sense of social responsibility and persuade them to have more children. Women should drop their claims to emancipation and return to their "natural" role as child rearers and homemakers. "Woman fails when she ceases to desire the children for which she was primarily made", wrote Grantly Dick-Read in Motherhood in the Post-War World. "Her true emancipation lies in freedom to fulfil her biological purposes". ${ }^{41}$ As mothers, women had a vital part to play in society, for mother love was the mainspring of progress and social renewal. From the seed of motherhood, a new spirit capable of altering civilisation would arise: poverty, distress and misery would be eliminated, individuals would be governed by the principle of service to the community, and cooperation rather than conflict would guide the relations among countries. Thus, while "cultural" labour symbolised the pathology of civilised societies, natural or physiological childbirth held up the promise of a return to a mythical pre-cultural state, rooted in the traditional values of rural society.

Dick-Read was a charismatic and controversial figure. He had many opponents and many devoted followers. Medical colleagues criticised the scientific basis of natural childbirth and its suitability to hospital practice. They objected to Dick-Read's emotional, florid style and claimed that the success of natural childbirth depended on his hypnotic personality. ${ }^{18}{ }^{42}$ At the same time, most did recognise that there was something to be said in favour of Dick-Read's patient centred approach—not least because it made mothers more cooperative.

Intolerant of criticism, Dick-Read was prone to antagonise medical colleagues. He evoked, however, an enthusiastic response in women, as his voluminous correspondence with the readers of his books testifies. ${ }^{43}$ It was a group of female sympathisers led by Mrs Prunella Briance who in 1956 founded the Natural Childbirth Association (later the National Childbirth Trust) for the purpose of spreading DickRead's teaching. ${ }^{44}$ Under the guidance of Dick-Read and Mrs Briance, the campaign associated natural childbirth with such values as religious morality, improving the race, reinforcing family life, and re-establishing the Empire. As Briance wrote (Newsletter 2, March 1957), "Babies born this way are better babies ... and we urgently need in Britain a race of good quality men and women".

Natural childbirth, however, was already losing ground to the "psychoprophylactic" technique advocated by the French obstetrician Ferdinand Lamaze. In 1958 the Natural Childbirth Association itself shifted its allegiance to Lamaze, despite Mrs Briance's protestations. Other childbirth organisations followed suit: thus, after Dick-Read's death in 1959 and for the next 15 years or so, it was the Lamaze method that dominated the field as the chief non-interventionist alternative to obstetric analgesia.

\section{PRIMITIVE CHILDBIRTH}

Dick-Read's critique of "cultured" labour resonates in the work of his contemporary Dr Kathleen Vaughan (d 1957), who was responsible for introducing the squatting position for delivery in this country. A graduate of London University, Vaughan was a pioneer in bringing medical care to Indian women and children. While working in Kashmir, she became interested in the part played by pelvic malformations in complicated births. Most of the cases of contracted pelvis she had to deal with were due to osteomalacia, a disease similar to rickets in children. However, unlike rickets, which was associated mainly with poverty, osteomalacia appeared to be endemic among the urbanised, affluent women who lived in the enforced seclusion of the purdah system. Vaughan noticed, much to her surprise, that the disease was unknown among the boatwomen and peasants who led active lives in the open air.

Vaughan believed that environmental factors were paramount in the aetiology of the disease. She claimed that osteomalacia was due to insufficient exposure to sunshine, lack of exercise, and excessive consumption of processed foods. ${ }^{45}$ These views echoed the theories of rickets advanced by Vaughan's contemporaries Paton, Findlay and Cathcart, of Glasgow University, who claimed that rickets was caused by lack of hygiene and exercise rather than by a deficiency of vitamins A and D. Like rickets, osteomalacia demonstrated that "unnatural" modes of life led to ill health, regardless of social class.

Reasoning by analogy, Vaughan argued that the conditions of life in modern civilised societies had so altered the normal shape of the pelvis that women were no longer capable of giving birth "naturally". Vaughan attached great importance to the squatting position for defecation and childbirth, a custom she had first observed in the Kashmiri countryside. She saw it as a form of gymnastics that kept the pelvic joints mobile and supple, arguing that neglect of this position in Western societies was a cause of constipation and dystocia. However, joint mobility could be to some extent restored if women practised 
the squatting position during pregnancy and adopted it for delivery. This simple measure would obviate the need for interference during labour, thus eliminating puerperal sepsis and preventing birth injuries, which were a major cause of mental defect. ${ }^{46}$

In Safe Childbirth Vaughan laid down the "three essentials" for successful childbirth: round pelvic brim; flexible joints; and natural position for birth, by which she meant squatting. Childbirth was a "gymnastic feat", and women could prepare for it by taking the cue from their primitive sisters. ${ }^{47}$ Sunshine, exercise, and a diet rich in whole foods would optimise the physical conditions necessary for a safe delivery:

"What is here suggested", she wrote in Safe Childbirth, "is merely a return to nature and the conduct of a natural process as women have conducted it for themselves from the beginning of the world" ${ }^{46}$

Vaughan's ideas were popularised in the 1940s by the growing army of obstetric physiotherapists who were claiming natural childbirth as their territory. In the 1950s, however, the safety and efficacy of her methods were questioned and squatting fell into disuse. ${ }^{2}$ It was not until the late 1970s that Vaughan's ideas were rediscovered, when a resurgent natural childbirth movement adopted squatting as a symbol of feminist resistance against the supine position required by the "active management" of labour.

\section{CONCLUSION}

During the 1970s the introduction of new technologies of monitoring and controlling labour revived lay and medical interest in natural childbirth. This was not the natural childbirth of Dick-Read and Vaughan, however, but of Frederick Leboyer and Michel Odent. It was no longer associated with pronatalism and eugenics, but with feminism and consumerism. Natural childbirth appealed to feminists because they saw obstetric technology as an attempt to control women's bodies. It also appealed to consumers, because they objected to modern obstetrics' reductionism and lack of concern for the "whole" patient. Both groups called for a different approach to maternity care, in which the technical aspects of childbirth were subordinated to its social, psychological, and spiritual dimensions. ${ }^{48}$

At first sight it might seem bizarre that the women's liberation movement should have aligned itself with natural childbirth, an ideology that had arisen in part as a conservative response to female emancipation. This was not a sign of intellectual confusion, however, but a direct consequence of the way in which the notion of nature has been constructed in Western culture. Nature has been defined chiefly in terms of binary oppositions such as woman and man, country and town, spirit and matter, and so on. Each polarity has its own history, but it has also developed related meanings to other dichotomies. Thus in Cyril Pink's thought, vegetarianism and meat eating were associated respectively with femininity and masculinity, while for Dick-Read the opposition between natural and cultural labour was expressed in terms of an opposition between the normal or physiological on the one hand, and the pathological on the other hand. In their critique of obstetrical technology, feminists turned for help to another dichotomy, that between oppressed and oppressor, and linked it to pre-existing notions about naturalness.

As the foregoing discussion has shown, "natural childbirth" is not easy to define, because at bottom it is a category of challenge, a tool for thinking about society generally and its state of health or illness. This sort of "worldview holism" has been ubiquitous in Western society, justifying both left and right critiques of medicine and society ${ }^{49}$ Since the 1970s natural childbirth has adapted to new cultural and historical conditions, but it remains a sensitive barometer of our unease with the conditions of contemporary society.

\section{Box 2: Summary points}

- Natural childbirth is an approach characterised by a bias towards physical and mental hygiene in the management of pregnancy and birth.

- It emerged in Britain in the interwar period as a conservative, antifeminist reaction to the demographic crisis of the early 20th century.

- The ideology of natural childbirth was a by-product of the health reform movement.

- Health reformers offered social regeneration through health policy. They believed that both reformist and hereditarian health policies were necessary for biological progress.

- Health reformers advocated a return to a more natural mode of life as a corrective to the materialist tendencies of orthodox medicine. They objected to the interventionist bias of contemporary obstetrics, arguing that the improvement of women's general health was the key to safe childbirth.

- The "philosophy of the natural" elaborated by health reformers entailed a return to the "state of nature" represented by the primitive.

- The definition of the "primitive" as physiological norm was bound up with beliefs about the pathological effects of civilisation.

- Natural childbirth is at bottom a tool for thinking about the state of health and illness abut society in general. As such it is an example of the "worldview holism" that has characterised antimodernist critiques of society in the 20th century.

\section{ACKNOWLEDGEMENT}

The original research on which this article is based was funded by the Wellcome Trust.

\section{REFERENCES}

1 Lawrence C, Weisz G. Medical holism: the context. In: Lawrence C Weisz $\mathrm{G}$, eds. Greater than the parts: holism in biomedicine 1920-1950. New York/Oxford: Oxford University Press, 1998: 1-22.

2 Ransom S, Nixon WCW. Psychophysical preparation for labour. In: Claye A, Bourne A, eds. British obstetric and gynaecological practice. London: Heinemann Medical Books, 1963: 1199-216.

3 Nye RA. Sociology and degeneration: the irony of progress. In: Chamberlin JE, Gilman SL, eds. Degeneration: the dark side of progress. New York: Columbia University Press, 1985.

4 Soloway RA. Demography and degeneration: eugenics and the declining birthrate in twentieth-century Britain. Chapel Hill and London: University of North Carolina Press, 1990

5 Pick D. Faces of degeneration: a European disorder c1848-1918. Cambridge: Cambridge University Press, 1989

6 Searle GR. The quest for national efficiency. Oxford: Blackwell, 1971.

7 Porter D. "Enemies of the race": biologism, environmentalism, and public health in Edwardian England. Victorian Studies 1991;34:159-78.

8 Porter D. Health, civilization and the state: a history of public health from ancient to modern times. London: Routledge, 1999.

9 Lewis J. The politics of motherhood: child and maternal welfare in England, 1900-1939. London: Croom Helm, 1980.

10 Davin A. Imperialism and motherhood. History Workshop 1978;5:9-65.

11 Kevles D. In the name of eugenics: genetics and the use of human heredity. New York: Alfred A Knopf, 1985.

12 Jones G. Social hygiene in twentieth century medicine. London: Croom Helm, 1986.

13 Crichton-Miller H. Preserving the race in post-war reconstruction. BM 1942;i:337.

14 Williams AS. Women and childbirth in the twentieth century: a history of the National Childbirth Trust Fund 1928-93. Thrupp: Sutton Publishing, 1997.

15 Lewis J. Mothers and maternity policies in the twentieth century. In: Garcia J, Kilpatrick R, Richards M, eds. The politics of maternity care: services for childbearing women in twentieth-century Britain. Oxford: Clarendon Press, 1990: 15-29.

16 Beinart J. Obstetric analgesia and the control of childbirth in twentieth-century Britain. In: Garcia J, Kilpatrick R, Richards M, eds. The politics of maternity care: services for childbearing women in politics of maternity care: services for childbearing women in

17 Miller LG. "Pain, parturition and the profession". In: Reverby S, Rosner $D$, eds. Health care in America: essays in social history. Philadelphia: Temple University Press, 1979: 19-44

18 Sandelowski M. Pain, pleasure and American childbirth: From the twilight sleep to the Read method 1914-1960. Westport, CT: Greenwood Press, 1984

19 Leavitt JW. Brought to bed: childbearing in America, 1750-1950. New York/Oxford: Oxford University Press, 1986 
20 Dick-Read G. The influence of the emotions upon pregnancy and parturition. In: Browne FJ, ed. Antenatal and postnatal care. London: J \& A Churchill, 1937: 101-21.

21 Saleeby C. Parenthood and race culture: an outline of eugenics. London: Cassell \& Co, 1909

22 Vaughan KO. Training for childbirth. Health Education Journal 1943;1:139-41

23 Taylor JW. The diminishing birth-rate and what is involved in it. BM 1904;i:427.

24 Loudon I. Death in childbirth: an international study of maternal care and maternal mortality 1800-1950. Oxford: Clarendon Press, 1992.

25 Bloch M, Bloch JH. Women and the dialectics of nature in eighteenth-century French thought. In: MacCormack CP, Strathern M eds. Nature, culture and gender. Cambridge: Cambridge University Press, 1980: 25-41.

26 Jordanova L. Natural facts: a historical perspective on science and sexuality. In: MacCormack CP, Strathern M, eds. Nature, culture and gender. Cambridge: Cambridge University Press, 1980: 42-69.

27 Engelmann GJ. Labour among primitive people. 2nd Ed. St Lovis: J H Chambers, 1883.

28 Tracy M, Leupp C. Painless childbirth. McClure's Magazine 1914:43:37-5

29 Mears FC. Midwifery of the present day (letter). BM 1906;i:773

30 Dick-Read G. Revelation of childbirth: the principles and practice of natural childbirth. London: Heinemann Medical Books, 1942

31 Randell M. Training for childbirth from the mother's point of view. London: J \& A Churchill, 1939

32 Fairbairn JS. Gynaecology with obstetrics: a textbook for students and practitioners. London: Humphrey Milford, 1928

33 Fairbairn JS. Are we satisfied with the results of ante-natal care? BM 1934;ii: 193-4

34 Pink C. The ideal management of pregnancy. London: Cassell \& Co, 1930

35 Pink C. The foundations of motherhood. 4th Ed. London: Cassell \& Co, 1947.
36 Pink C. Diet in relation to motherhood. London: London Vegetarian Society, 1932.

37 Rey R. The history of pain. Cambridge, MA: Harvard University Press, 1998.

38 Dick-Read G. Natural childbirth. London: Heinemann Medical Books, 1933.

39 Dick-Read G. Childbirth without fear. New York: Harper \& Bros, 1944.

40 Dick-Read G. Psychosomatic aspects of pregnancy. In: Kroger WS, Freed CS, eds. Psychosomatic gynaecology: including problems of obstetrical care. Philadelphia/London: W B Saunders, 1951: 77-97.

41 Dick-Read G. Motherhood in the post-war world. London: Heinemann, 1944.

42 Caton D. What a blessing she had chloroform: the medical and social response to the pain of childbirth from 1800 to the present. New Haven and London: Yale University Press, 1999.

43 Thomas M. Post-war mothers: childbirth letters to Grantly Dick-Read 1946-1956. Rochester: University of Rochester Press, 1997.

44 Kitzinger J. "Strategies of the early childbirth movement: a case-study of the National Childbirth Trust". In: Garcia J, Kilpatrick R, Richards M, eds. The politics of maternity care: services for childbearing women in
twentieth-century Britain. Oxford: Clarendon Press, 1990: 92-115. twentieth-century Britain. Oxford: Clarendon Press, 1990: 92-115.
5 Vaughan KO. The purdah system and its effect on motherhood:

45 Vaughan KO. The purdah system and its effect on motherhood: \& Sons Ltd, 1928

46 Vaughan KO. Safe childbirth: the three essentials. London: Baillière, Tindall and Cox, 1937

47 Vaughan KO. Exercises before childbirth. London: Faber and Faber Ltd, 1951 .

48 Oakley A. The captured womb: a history of the medical care of pregnant women. Oxford: Blackwell, 1986.

49 Rosenberg CE. Holism in twentieth-century medicine. In: Lawrence $C_{\text {, }}$ Weisz G, eds. Greater than the parts: holism in biomedicine 1920-1950. New York/Oxford: Oxford University Press, 1998: 1920-1950. 35 .

\section{MEDICAL ANNIVERSARY}

\section{William Withering (17 March 1741)}

W

iliam Withering (1741-99) was born into a family of physicians in Shropshire. His father was a successful physician at Wellington, and his maternal grandfather had delivered Samuel Johnson. He graduated from the University of Edinburgh (1766), went into practice in Stafford, near Wellington, and then moved to a consultant post in Birmingham. In 1766 he published a monograph on the flora of Great Britain and at about the same time began using foxglove (folk's glove, fairies' glove, or ladies' thimbles) for the treatment of dropsy. Digitalisation had come to stay.

He died of tuberculosis and is buried in a vault at Edgbaston Church. At his death a pun announced

"The flower of English medicine is Withering".-D G James 